\title{
DE BETEKENIS VAN ZGN. AANGEKLEDE SALDOBILJETTEN VOOR DE ACCOUNTANTSCONTROLE
}

\author{
door R. de Koning
}

In het januarinummer van dit blad komt de heer Vecht terug op zijn artikel in het juninummer 1971 over bovengenoemd onderwerp. Op het eerste artikel is gereageerd door Prof. Frielink en Drs. Nordemann in het juli/augustusnummer en door mij in het novembernummer 1971. Ik neem aan dat de Heer Vecht bij het schrijven van zijn tweede artikel dat in hoofdzaak een antwoord is aan Prof. Frielink nog geen kennis droeg van mijn reactie. Hij trekt namelijk wederom een parallel tussen de verhouding van het gecontroleerde bedrijf tot de bank en tot anderen, een parallel die, zoals ik betoogde, voorbijgaat aan het verschil in betekenis van de verschillende activa en passiva in het waardenkringloopproces.

Twee opmerkingen in het tweede artikel van de heer Vecht trokken meer in het bijzonder mijn aandacht:

1. Banken en giroinstellingen zouden vaak niet over de juiste gegevens beschikken omtrent degenen die gerechtigd zijn over het tegoed op een rekening te disponeren".

De strekking van deze uitspraak is mij niet duidelijk. De bank zal uiteraard slechts opdrachten uitvoeren afkomstig van personen die tot het geven van deze opdrachten krachtens gegeven en niet ingetrokken machtigingen of anderszins bevoegd zijn. Voor de bank is dat voldoende. Natuurlijk is het denkbaar dat het één en ander niet overeenstemt met de vermeende regeling van de bevoegdheden bij het bedrijf. De beoordeling van de beschikkingsbevoegdheden behoort uiteraard tot de taak van de accountant en als, zoals Vecht stelt, verschillen voorkomen tussen de werkelijke en de bedoelde situatie is dit slechts een reden te meer om van het controlemiddel van de aangeklede saldobiljetten gebruik te maken.

2. Het nut van angeklede saldobiljetten zou in ernstige mate worden aangetast door de kans dat de cliënt de bank bereid zou vinden om bepaalde informatie strikt vertrouwelijk tussen bank en cliënt te houden".

Ik neem aan dat in dit geval een bankverklaring geheel achterwege zal blijven, want ik weiger te geloven dat een bank op een verzoek waarin uitdrukkelijk gevraagd wordt om een opgave van alle verhoudingen een onvolledig antwoord zal geven. Het tegendeel veronderstellen lijkt mij onbehoorlijk tegenover het bankwezen.

$\mathrm{Nu}$ de Heer Vecht wederom een parallel trekt tussen de verhouding van het gecontroleerde bedrijf tot de bank en tot anderen wil ik van de gelegenheid gebruik maken mijn in mijn vorige artikel neergelegde visie nog wat te verduidelijken.

Ik heb hierin betoogd dat de verhoudingen tot leveranciers en afnemers moeten worden gezien als fasen in het waardenkringloopproces. De stand van de schulden aan leveranciers resp. van de vorderingen op afnemers op een bepaald moment representeert het faseverschil tussen ingaande goederen - en 
uitgaande geldstroom resp. uitgaande goederen - en ingaande geldstroom. De afwikkeling van deze schulden en vorderingen vormt een verlengstuk van de goederenbeweging.

Schmalenbach heeft dit in zijn „Dynamische Bilanz" reeds treffend gekenschetst met de woorden „Aufwand noch nicht Ausgabe" (met betrekking tot de schulden aan leveranciers) resp. „Leistung noch nicht Einnahme” (met betrekking tot vorderingen op afnemers).

In een op het waardenkringloopproces gebaseerd controleprogramma passen daarom met betrekking tot deze verhoudingen logisch ontstaans- en afloopcontrole, alsmede beoordeling van verhoudingen als gemiddelde krediettermijnen e.d. Normaliter zal er geen behoefte zijn aan saldobevestigingen.

Tussen ingaande en uitgaande geldstroom bestaat niet hetzelfde verband als tussen in- en uitgaande goederenstroom. In de ingaande geldstroom zijn de vergoedingen voor alle aangewende produktiemiddelen alsmede de winst begrepen. De uitgaande geldstroom omvat de voor verkrijging van produktiemiddelen aangewende bedragen alsmede de winstuitkering.

Het meten van de stand van de geldmiddelen op een bepaald moment (bij Schmalenbach „Geld") zal dientengevolge veelal het sluitstuk van een controleprogramma vormen. Hiervoor is voor wat betreft het banksaldo niet onder alle omstandigheden persé een bankverklaring nodig. Ik ben het met de heer Vecht eens dat een goede administratieve organisatie dit controlemiddel overbodig kan maken. Waar het mij om gaat is dat de geldmiddelen een ander karakter dragen dan de verhoudingen tot leveranciers en afnemers en daarom bij de controle een andere benadering vragen.

(Discussie gesloten) 